\begin{tabular}{c} 
(1) International Journal of Chemistry and Technology \\
$\frac{\text { http://dergipark.org.tr/ijct }}{\text { Research Article }}$ \\
\hline
\end{tabular}

\title{
Investigation dissolution behaviours and kinetics parameters of ulexite in boric acid solution
}

\author{
Dehmet Harbi ÇALIMLI ${ }^{1, *}$, (1) Mehmet TUNÇ ${ }^{2}$, (D) Mehmet Muhtar KOCAKERİM ${ }^{3}$ \\ ${ }^{1}$ Medical Services and Techniques Department, Tuzluca Vocational School, Igdir University, 76000 Igdir, Turkey \\ ${ }^{2}$ Department of Chemical, Science Faculty, Yuzuncu Yll University, 65100 Van, Turkey \\ ${ }^{3}$ Department of Chemical, Science Faculty, Çakırı Karatekin University, Çankırı, Turkey
}

Received: 10 May 2020; Revised: 20 July 2020; Accepted: 05 August 2020

*Corresponding author e-mail: mharbi.calimli@igdir.edu.tr

Citation: Çalımlı, M. H.; Tunç, M.; Kocakerim, M. M. Int. J. Chem. Technol. 2020, 4 (2), 121-129.

\begin{abstract}
Nowadays, boron and its derivatives are widely used in industrial and technological areas. Boron minerals are the main sources for obtaining pure boron chemicals in the usage of different applications such as the defense industry, health, industry, kitchen equipments, etc. In this paper, for the first time, it has been reported the dissolution behaviors and kinetics parameters of ulexite in the boric acid solution. To solve ulexite by boric acid is important, because boric acid as a solvent prevents the formation of impurities, and therfeore our study is a first in the literature. In this context, the dissolution of the ulexite has been investigated under various experimental parameters such as temperatures, acid concentration, solid/liquid ratio, particle size, dissolution rate, and stirring speed. The experimental findings shown that the dissolution kinetics of ulexite increase with an increase in temperature and acid concentration and a decrease in particle size, but decrease with mixing speed in the acid. Moreover, the dissolution of ulexite in boric acid and activation energy were evaluated. As a result, it was found that the dissolution kinetics were compatible with the chemical control model and the activation energy was $22.024 \mathrm{~kJ} \mathrm{~mol}^{-1}$.
\end{abstract}

Keywords: Ulexite, boric acid, dissolution, kinetic, activation energy.

\section{INTRODUCTION}

Many different boron minerals such as borax, tincal, colemanite, and ulexite are present and commercially important. Generally, almost all of these minerals are found in some different salt forms and all of these minerals contain B2O3. ${ }^{1-3}$ The increasing demand for
Uleksitin borik asit çözeltisinde çözünme ve kinetik parametre davranışlarının incelenmesi

ÖZ

Günümüzde bor ve türevleri yaygın olarak endüstri ve teknolojik alanlarda kullanılmaktadır. Bor mineralleri savunma sanayi, sağlık, mutfak ekipmanları vb. alanlarda kullanılan saf bor kimyasallarını elde etmek için ana kaynaklardır. Bu çalışmada, ilk kez, uleksitin borik asit çözeltisindeki çözünme davranışları ve kinetik paramaterleri rapor edilmiştir. Uleksiti borik asitte çözmek önemlidir, çünkü bir çözücü olarak borik asit safsızlıkların oluşumun engeller ve bu nedenle çalışmamız literatürde bir ilktir. Bu bağlamda, uleksitin çözünmesi, sıcaklıklar, asit konsantrasyonu, katı/sıv1 oranı, partikül boyutu, çözünme hızı ve karıştırma hızı gibi çeşitli deneysel parametreler altında incelenmiştir. Deneysel bulgular, üleksitin çözünme kinetiğinin sıcaklık ve asit konsantrasyonundaki artış ve partikül boyutundaki azalma ile arttığını, ancak asitteki karıştırma hızı ile azaldığını göstermiştir. Ayrıca, uleksitin borik asittteki çözmesi ve aktivasyon enerjisi değerlendirildi. Sonuçta özünme kinetiğinin kimyasal kontrol modeli ile uyumlu olduğu ve aktivasyon enerjisinin $22,024 \mathrm{~kJ} \mathrm{~mol}^{-1}$ olduğu bulundu.

Anahtar Kelimeler: Uleksit, borik asit, çözüme, kinetik, aktivasyon enerji.

boron mineral in different fields such as ceramic and glass industries, nuclear technology, refractors, catalysts, polymer production, increases the importance of boron minerals and derivatives. The examples of the current studies on ulexite and boron minerals include solidification of nuclear radioactive wastes, cementitebased composite neutron protection properties, and 
effects on borates' portland cement. ${ }^{4-7}$ These boron minerals mentioned are raw materials and used to produce boron compounds.

Ulexite is one of the raw materials and sources of boron elements used widely to produce boric acid, sodium perborate, etc. Ulexite as a hydrate contain sodium/calcium borate, and its formula has been detected as $\mathrm{Na}_{2} \mathrm{O} \cdot 2 \mathrm{CaO} \cdot 5 \mathrm{~B}_{2} \mathrm{O}_{3} \cdot 16 \mathrm{H}_{2} \mathrm{O}$. ${ }^{8-10}$ Boron oxide, sodium perborate, boric acid are some of the compounds obtained from boron minerals and applied commercially and widely in various applications. Boric acid has a wide usage area to obtain the boron mineral among these boron compounds. For example, various chemicals like boron carbide, boron halides, organic borate, borate carbide are produced using boric acid. Alkaline and alkali borates, metals mixed, acidic minerals, and crystallized boric acid are the other chemicals that are produced from boron minerals. Generally, commercial methods have been preferred to fabricate boric acid ${ }^{11,12}$ So far, various acids have been used by reacted with boron minerals to obtain boric acid.

In a study, ${ }^{13}$ colemanite was tested with sulfuric acid under different experimental parameters to obtain boric acid. However, forming gypsum as a precipitate by-product and the presence of boric acid in the liquid phase in this reaction are some of the harnesses such as sulfate contamination that cause environmental pollution. Furtherly, gypsum formation in the mentioned reaction exhibits the other adverse effects on soil and groundwater. ${ }^{14,15}$ Therefore, many different methods have been applied in various works. In these works, a lot of reactants such as nitric acid, chlorides, carbonate/sulfate of ammonia and caustic soda have been used to obtain boric acid from different boron minerals. ${ }^{2,16-18}$ To reveal behaviors of leaching, some different acids such as organic acids of citric acid, lactic acid, acetic acid, gluconic acid have been tested on different boron minerals. ${ }^{19-21}$ However, while the selectivity of organic acids is high, they are weak and exhibit low activity. ${ }^{3}$ Also, some inorganic acids such as ammonium nitrate, sulfur dioxide saturated water, sulfuric acid, hydrogen sulfate, ammonium chloride, and phosphoric acid have also been used in various studies related to ulexite. However, the mentioned inorganic acids cause the formation of undesirable byproducts that prevent obtaining pure yield. ${ }^{22-28}$ For the mentioned reasons, in this study, for the first time, we investigated the behaviors of dissolution boric acid that is a similar substance with $\mathrm{B}_{2} \mathrm{O}_{3}$ present in the composition of ulexite. Table 1 summarizes some studies conducted on ulexite and their activation energies.

Table 1. Some studies related to ulexite and their kinetic results

\begin{tabular}{clcc}
\hline Number & Acid and solution & $\begin{array}{c}\text { Activation } \\
\text { energy }\left(\mathrm{kJ} \mathrm{mol}^{-1}\right)\end{array}$ & Reference \\
\hline 1 & Acetic acid & 55.8 & 3 \\
2 & Ammonium acetate & 41.5 & 16 \\
3 & Ammonium acetate & 55.7 & 29 \\
4 & Ammonia solution saturated with $\mathrm{CO}_{2}$ & 55 & 30 \\
5 & Ammonium chloride & 80 & 31 \\
6 & Oxalic acid & 59.8 & 32 \\
7 & Boric acid & 22.02 & This study \\
\hline
\end{tabular}

In this study, we investigated the dissolution properties of ulexite in boric acid solution under different experimental parameters such as acid concentration, temperature, solid/liquid ratio, and ulexite particle size. Further, some activation parameters including activation energy and fitting kinetic modes were also determined. There is not available any papers related to boric acid in the literature, so we think the investigation of boric acid effect on ulexite dissolution is a very important issue. Additionally, we think that the current study will add novelties related to the extraction contents of boron mineral, especially for boric acid content.

\section{MATERIALS AND METHODS}

\subsection{Chemicals}

$\mathrm{NaOH}, \mathrm{HCl}$, EDTA used in the experiments were of analytical degree and used without any purification, and they were purchased from Sigma Aldrich. All glassware was cleaned with deionized water and ethanol. The ulexite used in the experiments was provided from Balikesir city in Turkey. Ulexite was cleaned to remove visible impurities and then crushed to obtain the desired particle size for use in experiments.

\subsection{Experimental procedure and the calculation of} B2O3 amount

The experimental route is based on that given elsewhere. $^{33,34}$ Ulexite dissolution experiments were carried out in a round bottom $250 \mathrm{ml}$ flask at room temperature and atmospheric pressure. The mixture was 
stirred using a thermostat mechanical stirrer to control the temperature of the reaction medium. A typical experiment was performed by transferring a $100 \mathrm{ml}$ boric acid solution into the reaction balloon and mixed for $15 \mathrm{~min}$ to reach the equilibrium temperature.

After this time, the desired amount of ulexite was added to this mixture and reaction launched at certain time intervals. The dissoluted ulexite at the end reaction was estimated by a complexometric technique conducted using the calcium ion $\left(\mathrm{Ca}^{2+}\right)$ determination method. ${ }^{33}$ In this method, after the interactions of ulexite and boric acid at the end of the experiment, the resulting solution was filtered and then the amount of $\mathrm{B} 2 \mathrm{O} 3$ in the latest solution was determined by stochiometric using reactions given below.

$$
6 \mathrm{H}_{3} \mathrm{BO}_{3(\mathrm{aq})}+12 \mathrm{H}_{2} \mathrm{O}_{(\mathrm{s})} \rightleftarrows 6 \mathrm{~B}(\mathrm{OH})_{4}^{-{ }_{(\mathrm{aq})}}+6 \mathrm{H}_{3} \mathrm{O}^{+}{ }_{(\mathrm{aq})}
$$

$\mathrm{Na}_{2} \mathrm{O} \cdot 2 \mathrm{CaO} \cdot 5 \mathrm{~B}_{2} \mathrm{O}_{3} \cdot 16 \mathrm{H}_{2} \mathrm{O}_{(\mathrm{k})}+6 \mathrm{H}_{3} \mathrm{O}^{+}{ }_{(\mathrm{aq})} \longrightarrow 2 \mathrm{Na}^{+}{ }_{(\mathrm{aq})}$ $+2 \mathrm{Ca}^{2+}{ }_{\text {(aq) }}+10 \mathrm{H}_{3} \mathrm{BO}_{3(\text { aq })}+10 \mathrm{H}_{2} \mathrm{O}_{(\mathrm{s})}$

Total reaction is summarized as
$\mathrm{Na}_{2} \mathrm{O} \cdot 2 \mathrm{CaO} .5 \mathrm{~B}_{2} \mathrm{O}_{3} \cdot 16 \mathrm{H}_{2} \mathrm{O}_{(\mathrm{k})}+2 \mathrm{H}_{2} \mathrm{O}_{(\mathrm{s})} \rightarrow 2 \mathrm{Na}^{+}{ }_{(\mathrm{aq})}+$ $2 \mathrm{Ca}^{2+}{ }_{(\mathrm{aq})}+6 \mathrm{~B}(\mathrm{OH})_{4(\mathrm{aq})}^{-}+10 \mathrm{H}_{2} \mathrm{O}_{(\mathrm{s})}+4 \mathrm{H}_{3} \mathrm{BO}_{3(\mathrm{aq})}$

The calculation procedure of $\mathrm{B}_{2} \mathrm{O}_{3}$ was carried out like follows.

Firstly, a $10 \mathrm{ml}$ solution taken from $100 \mathrm{ml}$ solution and diluted to $50 \mathrm{ml} .5 \mathrm{ml}$ of the resulting solution was taken and adjusted to $\mathrm{pH} 1$ by adding $\mathrm{NaOH}$ solution. This latest solution was titrated using mürecsil indicator and 0.02M EDTA solution.

Due to the equivalent grams of $\mathrm{Ca}^{2+}$ and $\mathrm{B}_{2} \mathrm{O}_{3}$, the conversion fraction of uleksit according to $\mathrm{B}_{2} \mathrm{O}_{3}$ was calculated from Eq. (4).

$X_{B_{2} O_{3}}=\frac{B_{2} O_{3} \text { amount passed to solution }}{\text { Total } B_{2} O_{3} \text { amount in the sample }}$

The experimental parameters tested in this study are given in Table 2.

Table 2. Experimental parameters tested on the dissolution ulexite in boric acid solutions

\begin{tabular}{ll}
\hline Parameters & Value \\
\hline Acid concentration $(\%$ in wt) & $1,3,4,6^{*}$ \\
Temperature $\left({ }^{\circ} \mathrm{C}\right)$ & $30,40^{*}, 50,60,70$ \\
Partical size $(\mathrm{mm})$ & $0.497,0.348,0.273,0.177^{*}$ \\
Stirring speed $(\mathrm{rpm})$ & $200,300,400^{*}, 500$ \\
Solid/liquid ratio $\left(\mathrm{g} \mathrm{mL}^{-1}\right)$ & $0.5 / 100,1 / 100,2 / 100,4 / 100$ \\
Time (min) & $3,5,10,15,20,30,40,50$ \\
\hline *Common parameters in all the experiments for dissolution ulexite in boric acid.
\end{tabular}

\section{RESULTS AND DISCUSSION}

3.1. The effect of temperature and acid concentration on the dissolution rate

The effect of reaction temperature on the dissolution of ulexite was studied at the temperatures of $30,40,50,60$, and $70^{\circ} \mathrm{C}$. The results obtained from the experiments are graphed in Figure 1a. As can be seen from this figure, the dissolution kinetics of ulexite increased with increasing temperature. According to the Arrhenius equation, the dissolution kinetics increased in direct proportion to the exponential function of the heat. Arrhenius equation is as follows:

$k=k_{0} \exp (-E / R T)$
Where, $E$ is activation energy $\left(\mathrm{J} \mathrm{mol}^{-1}\right) . R$ is universal gas constant $\left(\mathrm{J} \mathrm{mol}^{-1} \mathrm{~K}^{-1}\right) . T$ is absolute temperature (in Kelvin). $k$ is reaction rate. $k_{0}$ is reaction rate constant and refers to the number of collisions.

The effect of acid concentration on the dissolution of ulexite was investigated by using the acid concentrations of $1,3,4$ and $6 \%(\mathrm{w} / \mathrm{w})$ at the reaction temperature of $40^{\circ} \mathrm{C}$, the particle size of $0.213 \mathrm{~mm}$, the solid-to-liquid $0.01 \mathrm{~g} \mathrm{ml}^{-1}$, and stirring speed of 400 rpm. The results of the experiments are graphed in Figure $1 b$. As seen in Figure $1 b$, the dissolution rate increased with rising acid concentration. Because of the increase of acid concentration, the concentration of $\mathrm{H}_{3} \mathrm{O}^{+}$increased in the solution. Herein, $\mathrm{H}_{3} \mathrm{O}^{+}$acts as a reacting agent. These effects caused an increase in the dissolution rate. 
a)

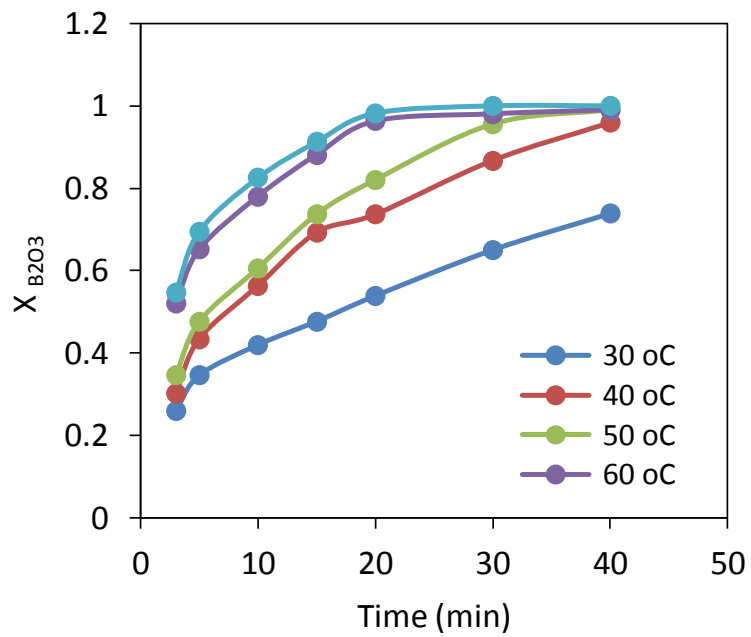

b)

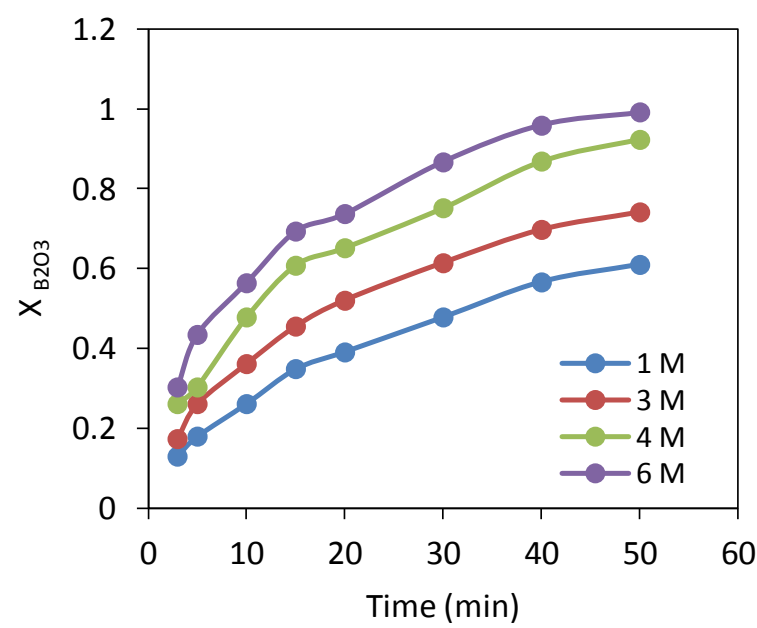

Figure 1. Effects of a) temperature. b) acid concentration on ulexite dissolution

3.2. The effect of particle size and stirring speed on the dissolution rate

To explain the effect of particle size, ulexite particles of $0.497,0.348,0.273,0.177 \mathrm{~mm}$ were prepared and tested at $40^{\circ} \mathrm{C}$, at a stirring speed of $400 \mathrm{rpm}$ and at a concentration of $6 \%(\mathrm{w} / \mathrm{w})$ of $0.01 \mathrm{~g} \mathrm{ml}^{-1}$. The results obtained are graphed in Figure 2a.

As seen in Figure 2a, the dissolution rate increased with decreasing ulexite size. Effect of stirring speed on the dissolution of ulexite was examined at 200, 300, 400, and $500 \mathrm{rpm}$ at a reaction temperature of $40^{\circ} \mathrm{C}$, the particle size of 0.177 , solid-to-liquid of $0.01 \mathrm{~g} \mathrm{ml}^{-1}$ and boric acid concentration of $\% 6(\mathrm{w} / \mathrm{w})$. a)

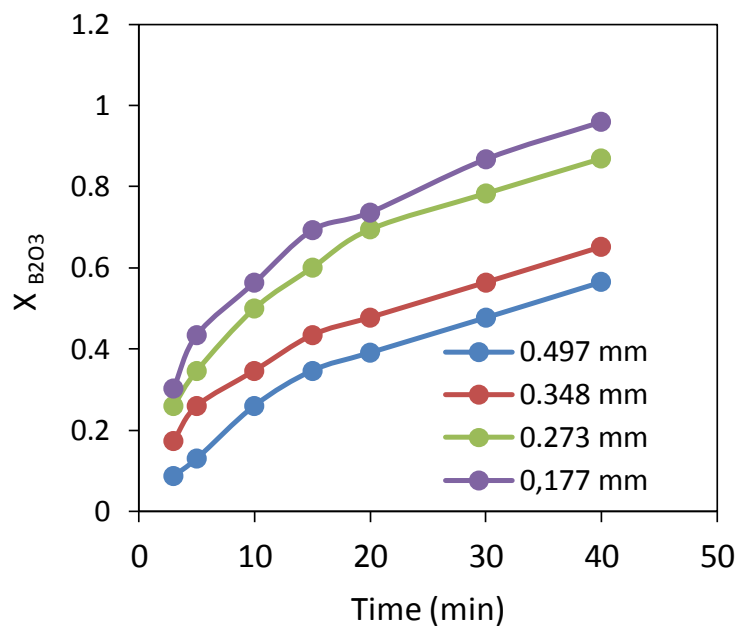

b)

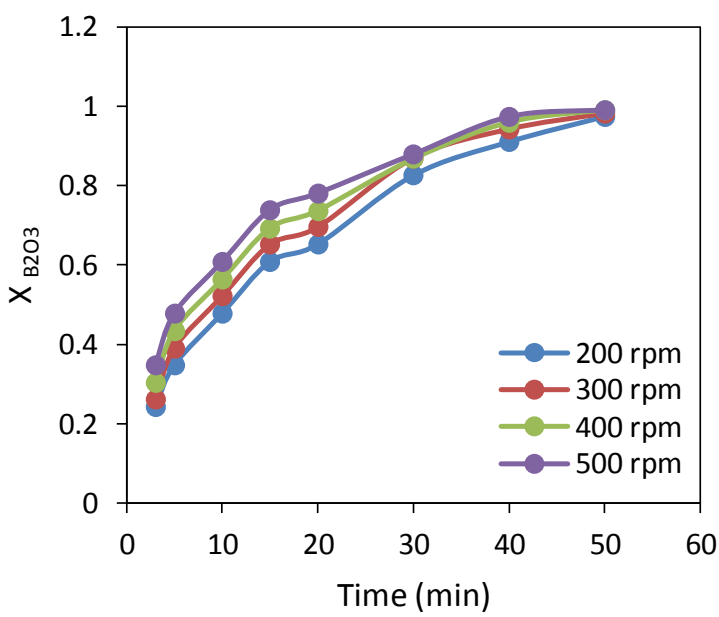

Figure 2. Effects of a) particle size, b) stirring speed on the dissolution of ulexite.

As seen in Figure 2b, the stirring speed had little effect on the dissolution of ulexite. Three different kinetic models were tested of ulexite. Three different kinetic models were teste to detect which parameter fits the dissolution rate of ulexite in the boric acid solution. As a result of these evaluations, the pseudo-homogeneous kinetic models were evaluated. The calculations and experimental results showed that the best kinetic model was found to be a chemical reaction control model as 1$(1-\mathrm{X})^{1 / 2}=\mathrm{kt}$.

Where, $X$ is $X_{B_{2} O_{3}}$ given in Eq. (4). According to this model, the graph of $1-(1-X)^{1 / 2}$ versus $t$ at different temperatures is shown in Figure 3. 


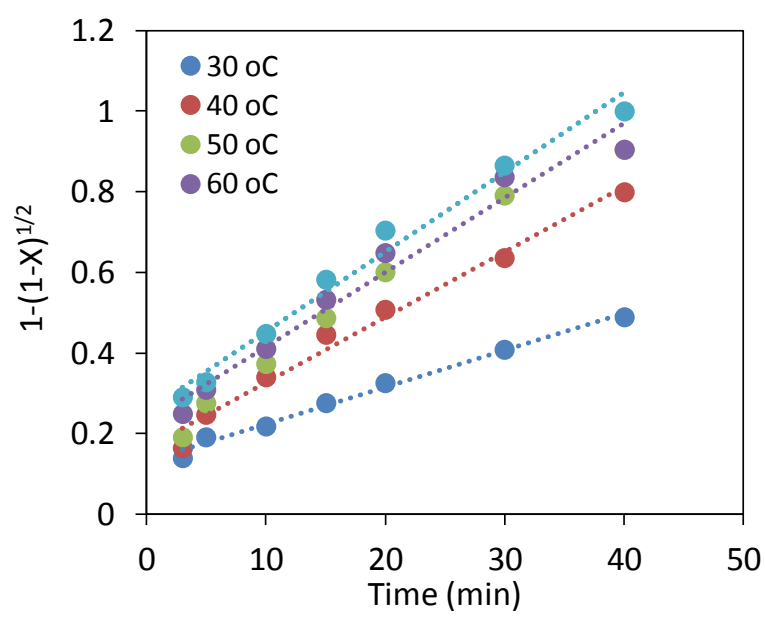

Figure 3. Agreement of experimental data with chemical reaction control model at different temperatures.

\subsection{Solid-to-liquid ratio on the dissolution rate}

The effect of solid-liquid ratio on dissolution of ulexite was investigated by taking $0.5 / 100,1 / 100,2 / 100,4 / 100$. The results obtained are graphed in Figure 4.

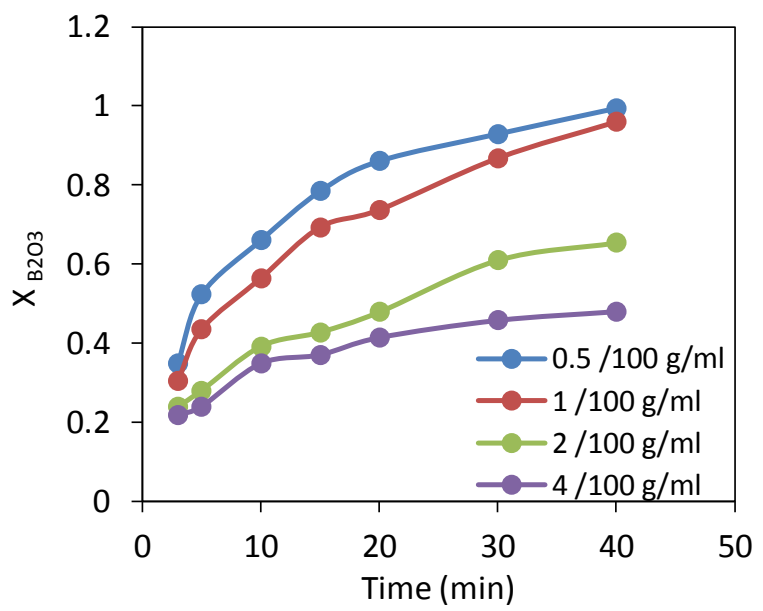

Figure 4. Effects of the solid-to-liquid ration on the dissolution of ulexite.

\section{4. Kinetic evaluation of ulexite dissolution in boric acid solution}

Chemical kinetics explains the progress of reactions, reaction steps, which eaction factors are connected, product formation conditions. Chemical reactions can occur in one phase (homogeneous reactions) or in more phases (heterogeneous reactions). The process used to dissolve the desired or undesirable products in a solution containing more than two phases are called leaching. ${ }^{35-38}$
Reaction systems are divided into two according to their phases as follows.

1. Homogeneous reactions: In such reactions, substances react and form in a single phase. Phases may be solid, liquid or gas. Homogeneous reactions can be studied catalytically or non-catalytically. ${ }^{39-41}$

2. Heterogeneous reactions: These reactions take place in at least more than two phases. There are some factors such as interface areas, temperature, pressure, the shape of the reaction vessel, fluid-phase diffusion characteristics that affect reaction rate. The systems used heterogeneous reactions have some properties such as solid-liquid compositions, the formation of a product surrounding solid yield, the variation of volume and shape of a solid product during the reaction. The variation shape of solid products and solid/ liquid interaction can cause undesired results. ${ }^{42-47}$ The reactions that will occur are listed below.

A (fluid) + B (solid) $\rightarrow$ Fluid Products

Fluid + Solid Reactants $\rightarrow$ Fluid Products

Fluid + Solid Reactants $\rightarrow$ Solid Products

Fluid + Solid Reactants $\rightarrow$ Fluid and solid product

Solid Reactants $\rightarrow$ Fluid products

Solid Reactants $\rightarrow$ Fluid and solid products

In reactions with the excessive liquid phase, the concentration is considered to remain constant during the reaction. ${ }^{33,35,38,41,47}$ The equations that is applied to systems where such a liquid component is constant and our evaluations of the results for different models are given in Table 3 .

The kinetics of the reaction between ulexite ore and boric acid were analyzed graphically and statistically using homogeneous and heterogeneous reaction models. The value of $\mathrm{R}^{2}$ was found as 0.9821 for the diffusion controlled kinetic model (Table 3), and this indicated that the diffusion control model from the fluid film was valid.

3.4.1. Dependence on particle size and acid concentration

Using the results of experiments with particle sizes of $0.497,0.348,0.273,0.177 \mathrm{~mm}$, affecting the conversion speed, $1-(1-X)^{1 / 2}$ values are obtained graph against $t$. From the slope of the plot in Figure 5a, the apparent rate constant $\left(k_{l}\right)$ values for each fraction were calculated. 
Table 3. Integer rate equations and regression coefficients for reaction kinetics

\begin{tabular}{|c|c|c|}
\hline Rate equations & Rate control types & $\mathbf{R}^{2}$ \\
\hline$k t=-\ln (1-X)$ & The homogeneous first phase reaction model & 0.7277 \\
\hline $\mathrm{kt}=1-3(1-\mathrm{X})^{2 / 3}+2(1-\mathrm{X})$ & $\begin{array}{l}\text { Ash (or product) for fixed-size particle diffusion-controlled } \\
\text { from the film. }\end{array}$ & 0.9447 \\
\hline $\mathrm{kt}=1-(1-\mathrm{X})^{1 / 3}$ & Controlled chemical reaction model. & 0.9799 \\
\hline $\mathrm{kt}=1-(1-\mathrm{X})^{1 / 2}$ & $\begin{array}{l}\text { Diffusion from the fluid film for the shrinking sphere } \\
\text { controlled. }\end{array}$ & 0.9821 \\
\hline $\mathrm{kt}=1-(1-\mathrm{X})^{2 / 3}$ & $\begin{array}{l}\text { Diffusion from the fluid film for shrinking sphere } \\
\text { controlled (small ones). }\end{array}$ & 0.9818 \\
\hline
\end{tabular}

The relation between the initial rate and particle size,

$k=k_{l}(R p)^{a}$

where, $\mathrm{k}$ is reaction rate. $k_{l}$ is reaction rate constant. $R p$ indicates particle size. $a$ is a constant depending on the number of particles. $k_{l}$ can be expressed as follows:

$k_{I}=k_{0}[C]_{0}^{b}(S / L)^{c}(\text { St.speed })^{d} e^{-E / R T}$

where $k_{l}$ is reaction rate, $k_{0}$ is the reaction rate constant depends on stirring speed, $[C]_{0}$ indicates initial acid concentration (M). $S / L$ is solid-liquid ratio. St.speed indicates mixing speed. $\mathrm{E}$ is activation energy. $R$ is universl gas contant $\left(8.314 \mathrm{~J} \mathrm{~mol}^{-1} \mathrm{~K}^{-1}\right) . T$ is temperatute $(\mathrm{K}) . b, c$, and $d$ are constants.

On the other hand, the linear form of Eq. (12) can be given as follows:

$\ln k=\ln k_{1}+a \ln R p$

The plot of $\ln k$ versus $\ln (R p)$ is shown in Figure 5a. From the lope of this plot, The value of $a$ was found to be -9412 .

The results calculated in Eq. (12) gives Eq. (15).

$k=k_{l}(R p)^{-0,9412}$

While analyzing the effect of acid concentration on conversion rate and the values of $1-(1-X)^{1 / 2}$, the plot of $\ln \left(k_{1}\right)$ versus $\ln \left(C_{0}\right)$ was obtained by using boric acid solutions of $1 \%, 3 \%, 4 \%$, and $6 \%$ (Figure $5 \mathrm{~b}$ ).

Relatioship between reaction rate constant $\left(k_{l}\right)$ and acid concentration can be given as follows
$k_{1}=k_{2}[C]_{o}^{b}$

From the linear form of this equation, the values of $\ln k_{l}$ against $\ln [C]_{0}$ values were plotted (Figure $5 \mathrm{~b}$ ) and the value of $b$ was found as 0.4420 from the slope of the obtained plot. Accordingly, Eq. (17) can be obtained as:

$k_{1}=k_{2}(R p)^{-0.9412}[C]_{0}^{0.4420}$

Here $k_{2}$ is independent of particle size and acid concentration.

3.4.2. Dependence on solid/liquid ratio and stirring speed

Using the values of $1-(1-X)^{1 / 2}$ and the results of experiments performed on the conversion rate with solid/liquid ratios of $0.5 / 100,1 / 100,2 / 100,4 / 100$ $\mathrm{g} \mathrm{ml}^{-1}$, Figure $6 \mathrm{a}$ was obtained according to the linear equation of Eq. (18).

$k_{2}=k_{3}(S / L)^{c}$

where, $k_{2}$ is the reaction rate, $k_{3}$ is the reaction constant and $c$ is a constant depends on solid/liquid rate. Figure 6 a shows the plot of $\ln (S / L)$ against $\ln k_{2}$. The value of $c$ fom the slope of the plot in Figure 6a was found -0.6450. According to this, the following equation can be obtained

$k_{2}=k_{3}(R p)^{-0.9412}[C]^{0.4420}(S / L)^{-0.6450}$

Where $k_{2}$ is reaction rate, $k_{3}$ is the reaction rate constant, $R p$ is particle size, $[C]$ is concentration, $S / L$ is solid/liquid ratio. 
a)

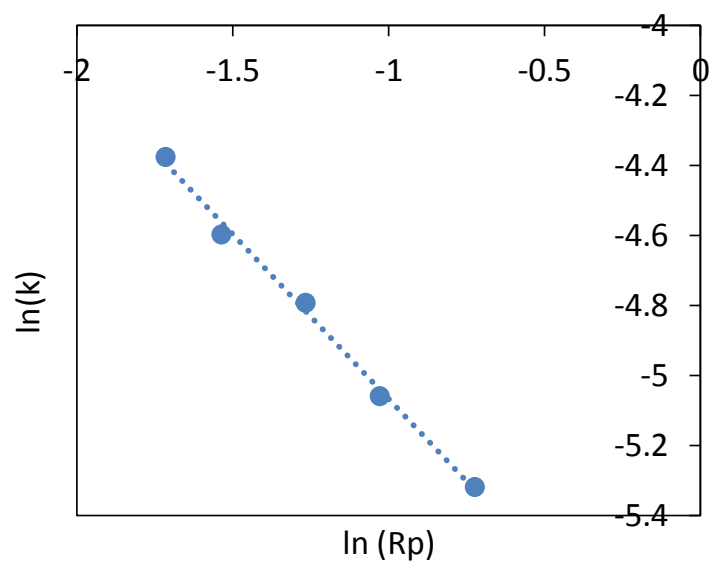

b)

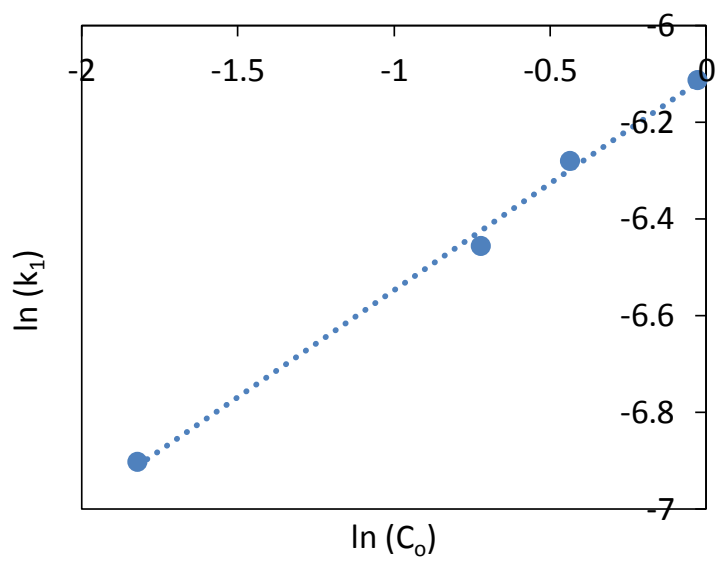

Figure 5. a) The plot of a) $\ln (k)$ versus $\ln R p$, b) the plot of $\ln \left(k_{l}\right)$ against $\ln C_{0}$.

The data of $1-(1-\mathrm{X})^{1 / 2}$ values and the results of the experiments of mixing speeds of 20.9439, 31.4159, $41.8879,52.3598$ radians / second of the conversion speed change were used in obtaining of Figure 6a using the linear form of Eq. (20).

$k_{3}=k_{4}(\text { St.speed })^{d}$

Where, $\mathrm{k}_{3}$ is reaction rate. $\mathrm{k} 4$ is a rate constant independent of the mixing speed. $d$ is the exponential constant.Figure $6 \mathrm{~b}$ shows the plot of $\ln k_{3}$ against $\ln$ (St.speed). The value of $d$ was determined as 0.0582 from the slope of the plot in Figure $6 b$.

According to this, Eq. (21) can be obtained.

$k_{3}=k_{4}(R p)^{-0.9412}[C]^{0.4420}(S / L)^{-0.6450}(\text { St.speed })^{0.05809}$ a)

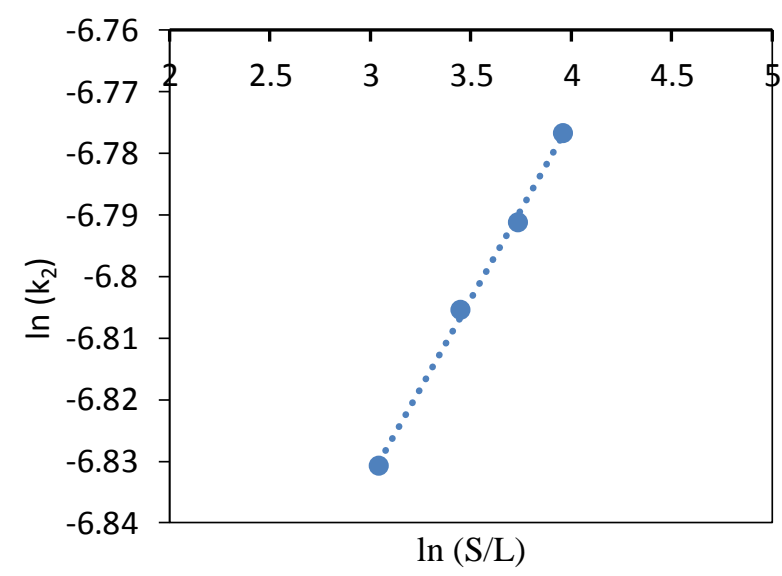

b)

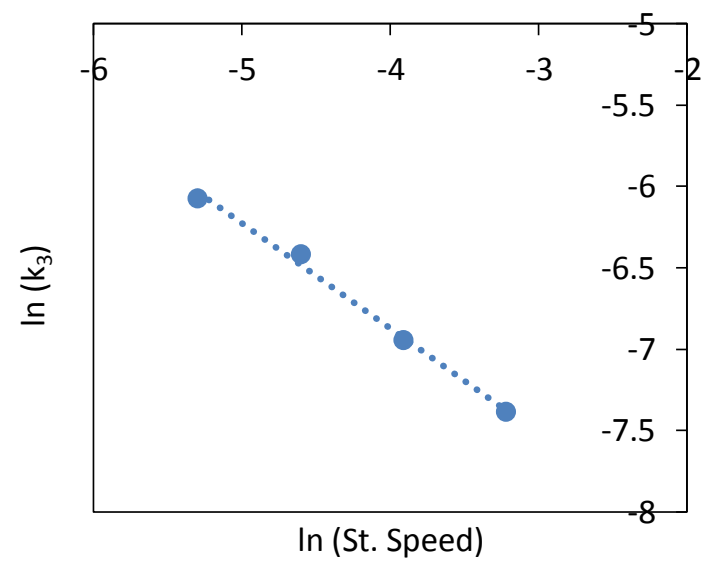

Figure 6. The plot of $\ln a)\left(k_{2}\right)$ against $\ln S / L$ ratio, b) The plot of $\ln \left(k_{3}\right)$ versus $\ln ($ St. speed $)$.

Where, ke is reaction rate. $k_{4}$ is a rate constant in dependent of particle size. [C] is acid concentration, $\mathrm{S} / \mathrm{L}$ is solid/liquid ratio. St.speed is mixing speed.

\subsubsection{Dependence on reaction temperature}

While examining the effect of reaction temperature on the conversion rate, the results of experiments with temperatures of $303,313,323,333$, and $343 \mathrm{~K}$ were obtained. Reaction rates obtained from the result of the experiments at different temperatures were used to obtain the Arrhenius graph in Figure 7. Arrhenius equation gives the change between reaction rate constant $\mathrm{k}_{4}$ and reaction temperature (Eq. 22).

$k_{4}=k_{0} \cdot e^{-E / R T}$ 
Assuming that there is a relation of the shape, $1 / T$ values are graphed against $\ln k_{4}$ values (Figure 7) and activation energy and Arrhenius constant were found from the slope of the plot obtained.

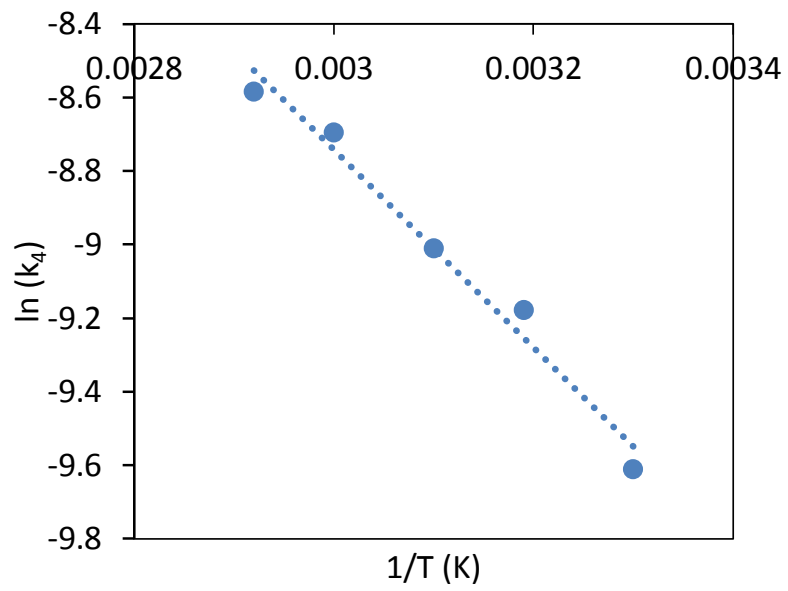

Figure 7. The plot of $\ln k_{4}$ versus $1 / T$ for ulexite reaction in boric acid.

The speed expression representing the transformation of the ulexite ore in the boric acid solutions by replacing the $a, b, c, d, E$ and $k_{0}$ values that show the effect of the parameters examined according to these results, a mathematical model was obtained as given below:

$$
\begin{aligned}
& 1-(1-X)^{1 / 2}=k_{4}(R p)^{-0,9412}[C]_{0}^{0,4420}(S / L)^{-0,6450} \\
& (\text { St.speed })^{0,05809} e^{-2649,1226 / T}
\end{aligned}
$$

Where $k_{4}$ is independent of paricle size. $R p$ is particle size. $[C]_{0}$ is initial acid concentration, $\mathrm{S} / \mathrm{L}$ is solid/liquid ratio. St.speed is mixing speed.

\section{CONCLUSIONS}

In summary, the findings of this study can be expressed as follows:

The common values of the parameters used in the experiments are: particle size $0.177 \mathrm{~mm}$, boric acid concentration $6 \%$, mixing speed $400 \mathrm{rpm}$, solid/liquid ratio $1 / 100 \mathrm{~g} \mathrm{ml}^{-1}$, reaction temperature $40^{\circ} \mathrm{C}$. And the following equations can be revealed

$$
\begin{aligned}
& 1-(1-x)^{1 / 2}=k t \\
& k=k_{0}(R p)^{a}[C]_{0}^{b}(S / L)^{c}(\text { St.speed })^{d} e^{-E / R T}
\end{aligned}
$$

Herein, the values of $\mathrm{a}, \mathrm{b}, \mathrm{c}, \mathrm{d}$ and $-E / R$ values were found as a: -1.013 , b: 0.4579 , c: -0.650 , d: 0.0545 , E/R: -2649.1226 , respectively.
By replacing these values, the speed expression representing the transformation of ulexite ore in boric acid solutions can be given as follows:

$1-(1-X)^{1 / 2}=\left[2.02(R p)^{-1,013}[C]_{0}^{0,4579}(S / L)^{-0,650}\right.$

$\left.(\text { St.speed })^{0,0545} e^{-2649,12 / T}\right] . t$

Herein, it has been obtained as a mathematical model.

In this study, it was found that the dissolution rate increased with the decrease in the particle size, the solid/liquid ratio, the acid concentration, and the reaction temperature. The mixing rate did not change the dissolution rate much. In all the experiments in which common parameters were kept constant, it was found that the best dissolution occurred at a temperature of $70^{\circ} \mathrm{C}$ for $40 \mathrm{~min}$.

\section{ACKNOWLEDGEMENTS}

The authors are grateful to YYÜ Scientific Research Projects Presidency for their financial support for project numbered 2013-FBE-D058.

\section{Conflict of interests}

Authors declare that there is no a conflict of interest with any person, institute, company, etc.

\section{REFERENCES}

1. Çavuş, F.; Kuşlu, S. Ind. Eng. Chem. Res. 2005, 44, 8164-8170.

2. Alkan, M.; Doğan, M.; Namli, H. Ind. Eng. Chem. Res. 2004, 43, 1591-1598.

3. Ekmekyapar, A.; Demirkiran, N.; Künkül, A. Chem. Eng. Res. Des. 2008, 86, 1011-1016.

4. Wei, C.; Ling, X.; Li, Q.; Yuan, B.; Li, B.; Ma, H. Constr. Build. Mater. 2019, 215, 777-785.

5. Piotrowski, T.; Glinicka, J.; Glinicki, M. A.; Prochoń, P. Constr. Build. Mater. 2019, 195, 583-589.

6. Sokol, E. V.; Sanderman, J.; Bradford, M.A. Chem. Geol. 2019, 525, 58-81.

7. Li, B.; Ling, X.; Liu, X.; Li, Q.; Chen, W. Cement Concrete Comp. 2019, 102, 94-104.

8. Temur, H.; Yartaşı, A.; Çopur, M.; Kocakerim, M. M. Ind. Eng. Chem. Res. 2000, 39, 4114-4119. 
9. Xia, Y. K.; Peng, F. F. Int. J. Miner. Process. 2007, 83, 68-75.

10. Demirkiran, N.; Künkül, A. Int. J. Miner. Process 2007, 83, 76-80.

11. Taylan, N.; Gürbüz, H.; Bulutcu, A. N. Ultrason. Sonochem. 2007, 14, 633-638.

12. Ruecroft, G.; Hipkiss, D.; Ly, T.; Maxted, N.; Cains, P. W. Org. Process Res. Dev. 2005, 9, 923-932.

13. Mergen, A.; Demirhan, M.H; Bilen, B. Adv. Powder Technol. 2003, 14(3), 279-293.

14. Kurtbaş, A.; Kocakerim, M. M.; Küçük, Ö.; Yartaşi, A. Ind. Eng. Chem. Res. 2006, 45, 1857-1862.

15. Ekinci, Z.; Şayan, E.; Beşe, A. V.; Ata, O. N. Int. J. Miner. Process 2007, 82 (4), 187-194.

16. Demirkiran, N.; Bayrakçi, N.; Asin, C. T. Nonferr. Met. Soc. 2013, 23, 1797-1803.

17. Ekmekyapar, A.; Künkül, A.; Demirkiran, N. Min. Proc. Ext. Met. Rev. 2010, 31, 250-255.

18. Künkül, A.; Aslan, N. E.; Ekmekyapar, A.; Demirkiran, N. Ind. Eng. Chem. Res. 2012, 51, 3612-3618.

19. Bayrak, B.; Laçin, O.; Bakan, F.; Saraç, H. Chem. Eng. J. 2006, 117, 109-115.

20. Laçin, O.; Dönmez, B.; Demir, F. Int. J. Miner. Process 2005, 75, 91-99.

21. Demir, F.; Laçin, O.; Dönmez, B. Ind. Eng. Chem. Res. 2006, 45, 1307-1311.

22. Demirkiran, N. Hydrometallurgy 2009, 95, 198-202.

23. Küçük, Ö.; Kocakerim, M. M. Chem. Eng. Process 2005, 44, 1005-1011.

24. Tunc, M.; Kocakerim, M. M.; Yapici, S.; Bayrakçeken, S. Hydrometallurgy 1999, 51, 359-370.

25. Kavci, E.; Çalban, T.; Çolak, S.; Kuşlu, S. J. Ind. Eng. Chem. 2014, 20 2625-2631.

26. Kuşlu, S.; Dişli, F. Ç.; Çolak, S. J. Ind. Eng. Chem. 2010, 16, 673-678.

27. Elbeyli, İ. Y. Hydrometallurgy 2015, 158, 19-26.

28. Doğan, H. T.; Yartaşi, A. Hydrometallurgy 2009, 96, 294-299.
29. Demirkiran, N. A. Chem. Eng. J. 2008, 141, 180-186.

30. Künkül, A.; Yapici, S.; Kocakerim, M. M.; Copur, M. Hydrometallurgy 1997, 44, 135-145.

31. Tekin, G.; Onganer, Y.; Alkan, M. Can. Metall. Quart. 1998, 37, 91-97.

32. Alkan, M.; Doğan, M. Chem. Eng. Process 2004, $43,867-872$

33. Çalban, T.; Çolak, S.; Yeşilyurt, M. Chem. Eng. Commun. 2005, 192, 1515-1524.

34. Ekmekyapar, A.; Demirkiran, N.; Künkül, A. Chem. Eng. Res. Des. 2008, 86, 1011-1016.

35. Künkül, A.; Yapici, S.; Kocakerim, M. M.; Copur, M. Hydrometallurgy 1997, 44, 135-145.

36. Hubli, R. C.; Mittra, J.; Suri, A. K. Hydrometallurgy 1997, 44, 125-134.

37. Crundwell, F. K.; Godorr, S. A. A Hydrometallurgy 1997, 44, 147-162.

38. Alkan, M.; Oktay, M.; Kocakerim, M. M.; Karagölge, Z. Hydrometallurgy 1991, 26, 255-262.

39. Maurice, D.; Hawk, J. A. Hydrometallurgy 1999, $51,371-377$

40. Herreros, O.; Quiroz, R.; Viñals, J. Hydrometallurgy 1999, 51, 345-357.

41. Tunc, M.; Kocakerim, M. M.; Yapici, S.; Bayrakçeken, S. Hydrometallurgy 1999, 51, 359-370.

42. El-Cheikh, F. M.; Khalil, S. A.; El-Manguch, M. A.; Omar, H. A. J. Chem. Educ. 1985, 62, 761.

43. Bancroft, W. D. J. Phys. Chem. 1924, 28, 973-983.

44. Abu-Eishah, S. I.; Anabtawi, M. J. J.; Isaac, S. L. Chem. Eng. Process 2004, 43, 1085-1094.

45. Onal, E. D.; Usluogullari, A. Eur. J. Integr. Med. 2012, 23, 12.

46. Li, P.; Rao, Q. H.; Li, Z.; Jing, J. T. Nonferr. Met. Soc. 2014, 24, 499-508.

47. Demir, H.; Özmetin, C.; Kocakerim, M. M.; Yapici, S.; Çopur, M. Chem. Eng. Process 2004, 43, 1095-1100. 